\section{Sponsored Research in Great Britain}

Facrlities for sponsored research in Great Britain were increased by the formation in 1957 of the Arthur D. Little Research Institute which has laboratories at Inveresk, Midlothian. The Institute is a non-profit-making organization registered in Great Britain as a company under the Friendly Societies Act, and although the two concerns are separate, it operates in close association with a similar group in the United States, Arthur D. Iittle, Inc., of Cambridge, Mass. The Institute has now issued its first annual report from which readers may gain some idea of the scope and objects of the new venture. With Lord Bilsland as chairman of the Board of Directors, and with Dr. F. N. Woodward as director of research, the Institute has been concerned with several projects, all of which are being treated with special reference to the fundamental scientific background. The results will normally be given open publication when the work is complete, and interim accounts of the various projects are given in this annual report. These projects include investigations of the sodium derivatives of sucrose and of their condensation with a variety of organic halogen compounds, studies on the mechanism of the formation of isotactic polymers, the development of rapid methods for assessing the effectiveness of potential corrosion inhibitors, studies on the mechanism of inhibition of corrosion by electrochemical methods, and investigations into the modification of wood cellulose by chemical methods. In addition, the report refers to lectures, publications and other scientific activities organized by the staff of the Institute. It will be of great interest to all those who wish to know more about this new development in sponsored research and its place in the general organization of research in Great Britain.

\section{Nuclear Studies in the United Kingdom}

The Science Department of the British Council has issued its third list (May 1959) entitled "Nuclear Studies". This is a concise catalogue of courses in pure and applied sciences concerned with the use and development of nuclear energy. It is issued primarily as a guide for the overseas student who wishes to undertake specialized, formal training in the United Kingdom. Consequently it includes only full-time courses, generally of one week or more in duration, and is not concerned with research topics or with the courses which may be regarded as forming part of a normal first-degree course. Although the list has appeared too late for application to be made for many of the courses during the academic year 1959-60, it serves to direct inquiries for courses in 1960-61. Further information can be obtained from the Science Department of the British Council, 65 Davies St., London, W.l.

\section{Building Research in New Zealand}

In recent years, a number of fields of investigation relating to the building industry in New Zealand have been pursued independently in various organizations and laboratories in which the main interests have been in quite different fields. The Dominion (Chemical) Laboratory has investigated paints and local building materials; the New Zealand Forest Service has carried out work on timbers, both indigenous and exotic, suitable for building; the Pottery and Ceramics Research Association has investigated the appropriate use of brick constructions for earthquake conditions; and the Dominion Physical Laboratory has done some valuable work on methods of domestic heating, thermal insulation, and related physical problems. But there has been no co-ordination between these diverse efforts; nor any institution wholly devoted to problems of the building industry.

This anomalous state of affairs is now to be abolished with the establishment of a Building Research Bureau, which is being sponsored by a joint committee of the New Zealand Master Builders' Federation and the New Zealand Institute of Architeets. Dr. Lyndon Bastings has been appointed the first director. It is intended initially to set up a library and an information service; but as funds allow, it is hoped that laboratories and other practical facilities will follow in due course. The address of the new Bureau is : Construction House, 66 Murphy Street, Wellington, N.1, New Zealand.

\section{Postgraduate Courses at the Imperial College of Science and Technology, London}

Advanced postgraduate study has long been a special feature of the work of the Imperial College of Science and Technology, University of London. As new types of technology emerge - of which nuclear power and soil mechanies are notable recent examples - they open up possibilities of study which must remain outside the scope of any course for a first degree but which are properly within the field of university teaching. The postgraduate courses at the College have been greatly increased in number in recent years to meet the wide range of technological development. Postgraduate courses provide the opportunity for students, including many who have already spent a year or more in industry, to further their knowledge in a particular specialized field, and at the same time to learn from experts their experience of the application of this knowledge in industry. Details of the courses are set out in an impressive handbook published by the College (Postgraduate Courses, 1959-60. Pp. xii +111 . London: Imperial College of Science and Technology, 1959); the list should give considerable satisfaction to all who are concerned with Britain's place in the world of tech. nology. Many of these courses have been accepted by the Department of Scientific and Industrial Research as suitable for the tenure of advanced course studentships. Grants for the courses related to agricultural science are awarded by the Ministry of Agriculture, Fisheries and Food. The courses are assisted by industry; in particular, a number of firms support the work of the advisory committees in concrete technology and technical opties and provide bursaries for the respective courses.

\section{Sandwich Course in Executive Development}

THE Department of Commerce and Management of Sheffield College of Technology is to provide a sandwich course in executive development commencing in November 1959. The purpose is to provide for the young manager and potential manager a fully integrated plan of executivo development, by bringing together in one scheme both education for management within the College and general and vocational managerial experience in his working environment. Full-time attendance at the College will be required for approximately fifteen weeks during each year of the course, and will be spread over a period of two academic years. Only students already engaged in industry, and individually 